\title{
The Influenec of Azolla pinnata on Floodwater Chemistry, Grain Yield and Nitrogen Uptake of Rice in Dano, Southwestern Burkina Faso
}

\author{
Benedicta Y. Fosu-Mensah ${ }^{1,2}$, Paul L. G. Vlek ${ }^{2}$, Günther Manske² \& Michael Mensah ${ }^{3}$ \\ ${ }^{1}$ Institute for Environment and Sanitation Studies (IESS), Univeristy of Ghana, Legon, Accra, Ghana \\ ${ }^{2}$ Center for Development Research, University of Bonn, Bonn, Germany \\ ${ }^{3}$ Department of Architecture, College of Architecture and Planning, Kwame Nkrumah University of Science and \\ Technology, Kumasi, Ghana
}

Correspondence: Benedicta Y. Fosu-Mensah, Institute for Environment and Sanitation Studies (IESS), Univeristy of Ghana, P. O. Box 209, Legon, Accra, Ghana. E-mail: yayrafosub@yahoo.com

Received: March 22, 2015 Accepted: May 31, 2015 Online Published: July 15, 2015

doi:10.5539/jas.v7n8p118 URL: http://dx.doi.org/10.5539/jas.v7n8p118

\begin{abstract}
Nitrogen fertilizer recovery by lowland rice can be as low as $10 \%$ and rarely exceeds $60 \%$. Azolla contributes to the nitrogen $(\mathrm{N})$ nutrition of rice plant through biological $\mathrm{N}$ fixation (BNF). This study aimed at assessing the influence of Azolla pinatta on floodwater chemistry, rice yield, total dry matter and $\mathrm{N}$ uptake of rice. The study was carried out at the Dreyer Research Station in South Western Burkina Faso in 2005 using a split urea application method called Experiment 1 (E1) which was compared with what the farmer's practice (E2), which is basal application of NPK (16 16 16) and one top-dress of urea. Four levels of nitrogen was used in the experiments $\left(0,40,80,120 \mathrm{~kg} \mathrm{~N} \mathrm{~h}^{-1}\right)$. The full Azolla cover on the floodwater surface by the time of urea application prevented rapid increase in floodwater $\mathrm{pH}$ in the range of 0.52 to 0.68 . The presence of Azolla lowered floodwater temperature by 1.9 to $2.0{ }^{\circ} \mathrm{C}$. There was a significant increased $(p<0.01)$ in total dry matter yield of rice by $7.8 \%$ in E1 and $9.8 \%$ in E2 as a results of the presence of Azolla on floodwater surface. Similarly, Azolla significantly $(p<0.01)$ increased grain yields in both experiments. Apparent N-recovery of rice increased between 13.3 and $16.8 \%$ in grain and 39.1 and $42.6 \%$ in straw. There was however no significant interaction $(p>0.05)$ between Azolla and nitrogen. It is concluded that Azolla brought about an additive effect and could be an efficient fertilizer alternative or supplement in flooded rice cropping system in Dano.
\end{abstract}

Keywaords: Azolla, nitrogen, temperature, rice, Ammonia volatilization and efficiency

\section{Introduction}

Nitrogen $(\mathrm{N})$ fertilizer uptake and use efficiency is often low because of its loss from the soil through various chemical and biochemical process. Nitrogen recovery by rice can be as low as $10 \%$ and rarely exceeds $60 \%$ (Fageria et al., 2009; Bandyopadhyay \& Sarkar, 2005; Fageria \& Baligar, 2001; Vlek \& Byrnes, 1986; Schnier et al., 1988). The losses of applied $\mathrm{N}$ fertilizer, particularly as gas, are typically higher in lowland rice ecosystems with saturated or flooded soil than in cropping systems with aerated soil (Zhu, 1997). Ammonia $\left(\mathrm{NH}_{3}\right)$ volatilization, a gaseous emission of $\mathrm{NH}_{3}$ to the atmosphere, is reportedly one of the major causes of the low $\mathrm{N}$ fertilizer efficiency and an important mechanism for $\mathrm{N}$ losses in lowland rice fields (Knoblauch et al., 2012; Jayaweera \& Mikkelsen, 1990; Freney et al., 1993). The most important factor in $\mathrm{NH}_{3}$-volitalization is a high $\mathrm{NH}_{4}$-concentration of the floodwater combined with high $\mathrm{pH}$ (Vlek \& Stumpe, 1978). The latter is closely related to the decomposition of urea and the photosynthetic activity of algae (Fillery \& Vlek, 1986; Freney et al., 1995).

In West Africa, most smallholder farmers are unable to purchase fertilizer to boost crop production due to the high cost of mineral fertilizers (Fosu et al., 2004). The low efficiency of $\mathrm{N}$ by rice and the high losses of $\mathrm{N}$ applied resulting in low yield causes substantial economic loss to farmers (Bandyopadhyay \& Sarkar, 2005; Song, 2004; De Macale \& Vlek, 2002) and pollution of the environment. In Burkina Faso most soils are deficient in nitrogen which is a major constraint to food production.

Globally, attention has been drawn to this problem and technologies are being develop to reduce the high $\mathrm{N}$ loss and improve $\mathrm{N}$ use efficiency by rice. The techniques which reduce $\mathrm{NH}_{3}$ volatilization losses would be expected 
to reduce total gaseous $\mathrm{N}$ losses (Simpson et al., 1988). Several options to increase the urea efficiency were investigated in last three decades, mainly by reducing the $\mathrm{NH}_{4}{ }^{+}$concentration in the floodwater by using urea super-granules (Vlek \& Craswell, 1981), urease inhibitors (Byrnes \& Freney, 1995), and slow-release products such as SCU (Blaise \& Prasad, 1995). Most of these methods are difficult to apply and requires chemicals that are expensive. With the exception of urea-supergranules, the others have found little adoption in the developing countries. To reduce environmental pollution, it is important to increase nitrogen use efficiency by integrating organic fertilizers in the rice production system. The use of Azolla has generated much interest to improve the efficiency of applied urea fertilizer (Vlek et al., 1992; Boadilla, 1993; Vlek et al., 1995; Cisse, 2001, De Macale \& Vlek, 2002). This aspect of Azolla use is new and has the potential of increasing yield, however, little is reported about this in Africa.

Azolla, an aquatic fern that lives in symbiosis with algae (anabaena), has high $\mathrm{N}$-fixing abilities, rapid growth and easy-decomposable characteristics (De Macale \& Vlek, 2002). It also acts as a recycling source of phosphorus, sulphur and other essential nutrients to the rice plant (Mian \& Azmal, 1989). Azolla contributes to the $\mathrm{N}$ nutrition of rice plant through biological $\mathrm{N}$ fixation (BNF) and hence has been used as bio-fertilizer especially in Asia (Lumpkin \& Plucknett, 1982; Mian, 1993). There is however litle research report of its use as biofertilizer in Burkina Faso where farmers are unable to purchase fertilzer for their crops due to high cost. This research aimed to evaluate the influence of Azolla on the floodwater chemistry, grain yield and $\mathrm{N}$ uptake of rice in Azolla/rice-based cropping systems in Dano (Burkina Faso).

\section{Materials and Methods}

\subsection{Study Area}

The study was conducted in the Dreyer Research Station at Dano (South Western Burkina Faso) in the Ioba province (longitudes $3^{\circ} 9^{\prime} \mathrm{W}$ and $3^{\circ} 6^{\prime} \mathrm{W}$ and latitudes $11^{\circ} 18^{\prime} \mathrm{N}$ and $3^{\circ} 4^{\prime} \mathrm{N}$ ). The soil is Gleysol characterized by permanent or temporary saturation of underground water. Monthly rainfall (Figure 1a), minimum and maximum temperature (Figure 1b) during the study period were obtained from the GLOWA-VOLTA meteorological station in Dano. This region is characteristiced by two marked seasons, a long dry season from October to April and a short rainy season from May to September. The rainfall varies from $300 \mathrm{~mm}$ in the extreme north to 1100 $\mathrm{mm}$ in the extreme south and south-west.

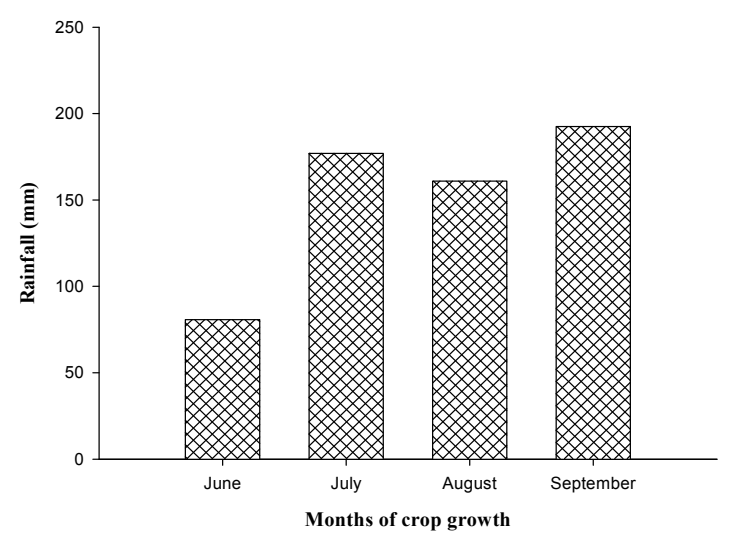

Figure 1a. Monthly rainfall distribution at the site during the experimental period. On-station field experiment in Dano, Burkina Faso 


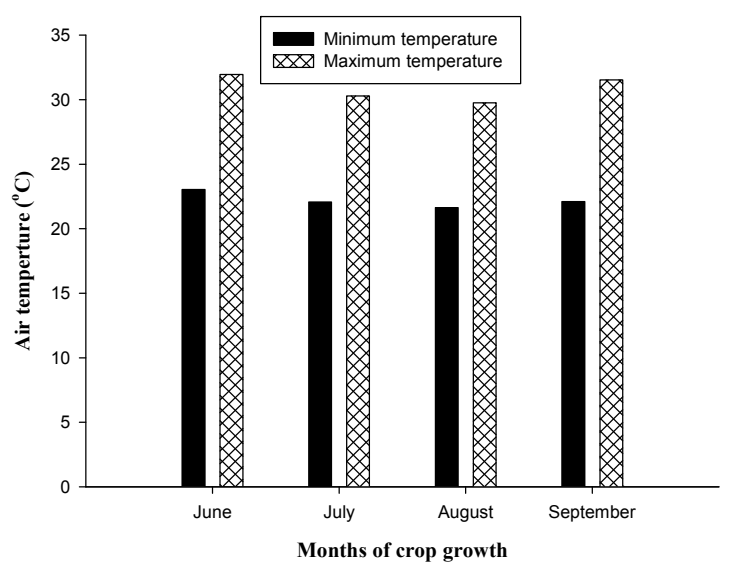

Figure $1 \mathrm{~b}$. Monthly minimum and maximum temperature distributions at the study site during the experimental period, On-station field experiment

\subsection{Experimental Layout and Treatments}

Two field experiments were carried out during the wet season in 2005 to evaluate the use of Azolla in combination with different rates of urea as a management technique to improve $\mathrm{N}$ uptake and grain yield of rice. Sixteen treatment combinations (Table1) consisting of four concentration of nitrogen fertilizer $(0,40,80$ and 120 $\mathrm{kg} \mathrm{N} \mathrm{ha}{ }^{-1}$ ) were applied with or without Azolla and control treatment. Two set of fertilizer application methods were employed. Except for the control, Potassium $(\mathrm{K})$ and phosphorus $(\mathrm{P})$ were applied in the form of potassium chloride (KCl) and triple super phosphate (TSP) each at the rate of $32 \mathrm{~kg} \mathrm{ha}^{-1}$ prior to transplanting and urea as a split dose, half at one week after transplanting and the other half at panicle initiation to experiment 1 (here after referred to as E1) and N P K (16-16-16) at a rate of $150 \mathrm{~kg} \mathrm{ha}^{-1}$ applied prior to transplating and urea fertilizer applied on 45 days after transplanting as a single dose in experiment 2 (hereafter refers to as E2), which is the usual practice of farmers. The levels of $\mathrm{P}$ and $\mathrm{K}$ were the same in all treatments. The experiments were laid out in a Randomized Complete Block Design (RCBD) with four replicates. Each plot size was $6 \mathrm{~m}^{2}(2 \mathrm{~m} \times 3 \mathrm{~m})$, with bunds of $50 \mathrm{~cm}$ surrounding it to prevent cross contamination of treatments between plots. All plots were flooded to a depth of $5 \mathrm{~cm}$ for two days before Azolla inoculation till two (2) weeks before harvest. The fertilizer commonly available and used by farmers, NPK (16-16-16) was used in the E2.

Table 1. Experimental treatments

\begin{tabular}{llll}
\hline Nitrogen concerntration $\left(\mathrm{kg} \mathrm{ha}^{-1}\right)$ & Azolla Pinnata $\left(\mathrm{t} \mathrm{ha}^{-1}\right)$ & Urea split application (E1) & Urea single dose (E2) \\
\hline 0 (control) & 0 & $\mathrm{~N} 1$ & N1f \\
0 & 2 & $\mathrm{~N} 2$ & N2f \\
40 & 0 & $\mathrm{~N} 3$ & N3f \\
40 & 2 & $\mathrm{~N} 4$ & N4f \\
80 & 0 & $\mathrm{~N} 5$ & N5f \\
80 & 2 & $\mathrm{~N} 6$ & N6f \\
120 & 0 & $\mathrm{~N} 7$ & N7f \\
120 & 2 & $\mathrm{~N} 8$ & N8f \\
\hline
\end{tabular}

\subsection{Planting Materials}

Rice seeds (Oryza sativa), variety FKR 19 (120-days maturity) was planted at a rate of $40 \mathrm{~kg} \mathrm{ha}^{-1}$. Before planting, the seeds were soaked for 24 hours and incubated for another 24 hours. The pre-germinated seeds were nursed on seedbed for twenty-two days. The seedlings were transplanted $20 \times 20 \mathrm{~cm}$ apart at 2 to 3 seedlings per hill. Re-filling of dead and weak seedlings was done four days after transplanting (DAT) to ensure uniformity in growth and density per hill.

Azolla pinnata was obtained from Vallee du Kou in the Houet province and multiplied in a propagating pond 
near the sites of the experiments. The Azolla was harvested, drained and weighed a day prior to the inoculation, that is, a week before rice transplanting. Ten percent of the floodwater surface was inoculated with Azolla at the rate of $2 \mathrm{t} \mathrm{ha}^{-1}\left(0.2 \mathrm{~kg} \mathrm{~m}^{-2}\right)$ in plots with Azolla treatments in order to obtain a complete cover of the floodwater with Azolla at the time of urea application.

\subsection{Soil Sampling and Field Measurements}

Soil samples were taken using soil auger at the depths of 0-15 cm and $15-30 \mathrm{~cm}$ from each plot.

Samples were air dried and passed through a $2 \mathrm{~mm}$ sieve, and soil analysis carried out to determine soil $\mathrm{pH}$, available P (Bray 1), total N [micro Kjeldahl distillation and titration method (Bremner \& Mulvaney, 1982)] and soil organic carbon (Walkely Black) (Table 2).

Table 2. Physical and chemical characteristics of sites of experiments at Dano, Burkina Faso

\begin{tabular}{lll}
\hline \multirow{2}{*}{ Characteristics } & \multicolumn{2}{c}{ Soil depth $(\mathrm{cm})$} \\
\cline { 2 - 3 } & $0-15$ & $15-30$ \\
\hline $\mathrm{pH}$ & 6.83 & 6.70 \\
Total nitrogen $(\%)$ & 0.08 & 0.07 \\
Exchangeable $\mathrm{K}\left(\mathrm{cmol} \mathrm{kg}^{-1}\right)$ & 0.14 & 0.11 \\
Exchangeable Ca $\left(\mathrm{cmol}^{\mathrm{kg}}\right)$ & 26.60 & 26.58 \\
Available $\mathrm{P}\left(\mathrm{mg} \mathrm{kg}^{-1}\right)$ & 4.30 & 3.61 \\
Organic matter $(\%)$ & 0.092 & 0.091 \\
CEC $\left(\mathrm{cmol} \mathrm{kg}{ }^{-1}\right)$ & 31.51 & 31.01 \\
Bulk density $\left(\mathrm{g} \mathrm{cm}^{-3}\right)$ & 1.25 & 1.44 \\
Soil texture & fine sand & fine sand \\
\hline
\end{tabular}

Floodwater temperature and $\mathrm{pH}$ were measured in situ in each plot the first 14 days after each urea application between 12 noon - 2 pm with a portable digital-pH/mV/Thermo-meter (GPRT 1400 AN) which has a metal probe thermometer $\left(-20\right.$ to $\left.+110{ }^{\circ} \mathrm{C}\right)$. Prior to inoculation, Azolla was sub-sampled, sun-dried, ground and analyzed for total nitrogen. Floodwater $\mathrm{pH}$ and temperature were measured in $\mathrm{E} 2$ only when $\mathrm{N}$ was applied in the form of urea at 45 days after transplanting while floodwater $\mathrm{pH}$ and temperature were measure one week and 45 days after transplant when urea was applied in E1.

Plant height were measured and tillers counted at two weeks intervals from six randomly selected tagged hills in each plot from two weeks after transplanting to panicle initiation stage. At maturity, 35 hills $\left(1.5 \mathrm{~m}^{2}\right)$ from the central part of each plot were cut at the base and threshed to separate the grains. The harvested grain from each plot was then weighed and the grain moisture content measured. The grain yield was oven dried at $70{ }^{\circ} \mathrm{C}$ for 48 hours and later corrected to $14 \%$ moisture content. To measure the straw oven-dry weight (StODW), the total fresh straw weight of the 35 hill sampled (StFW35hill) was first weighed and recorded after removing all spikelets. A sub-sample of 250 grams was taken for drying. This sub-sample weight was recorded (StFWss). The straw sub-samples were dried at $70{ }^{\circ} \mathrm{C}$ until it attained a constant weight. The final oven dry weight $\left(\mathrm{StODW}_{\mathrm{ss}}\right)$ was recorded. Plants samples were taken at panicle initiation stage and at harvest, oven dried, ground and sent to the Plant Nutrition Unit of the Faculty of Agriculture, University of Bonn, in Germany for N analysis. The N concentration was measured using the Kjeldahl digestion method (Anderson \& Ingram, 1996). Total aboveground biomass yield was also determined.

\subsection{Statistical Analysis}

The General Linear Model (GLM) analysis of variance (ANOVA) was used to compare the effect of the presence of Azolla on floodwater surface, $\mathrm{N}$ application and method of $\mathrm{N}$ application and their interactive effects on floodwater $\mathrm{pH}$, floodwater temperature, grain yield, straw yield, total biomass and apparent nitrogen recovery (ANR) using SPSS version 16. The LSD test for pairwise comparison of means was used to identify significant differences. Except for the floodwater $\mathrm{pH}$ and temperature which were analyzed separately, all other parameters were analyzed together. 


\section{Results}

\subsection{Floodwater Chemistry}

\subsubsection{Floodwater $\mathrm{pH}$}

In both E1, which is split urea treatment and E2 (which is basal application of NPK (16 16 16) and one top-dress of urea), Azolla constantly kept the floodwater $\mathrm{pH}$ below 8.0 for 14 days after urea application (Figures 2 and 3 ). The presence of Azolla cover on floodwater significantly $(p<0.01)$ reduced floodwater $\mathrm{pH}$ from the second day of urea application till the fourteenth day. The presences of Azolla cover reduced floodwater $\mathrm{pH}$ up to 1.2 units on the sixth day in N4 in E1 and 1.4 units in N8 on the seventh day in E2. This represents 12.8 and 16.5\% reduction respectively in the presence of Azolla. A peak of 8.63 was recorded in $120 \mathrm{~kg} \mathrm{ha}^{-1}$ without Azolla cover (N7f) in E2.

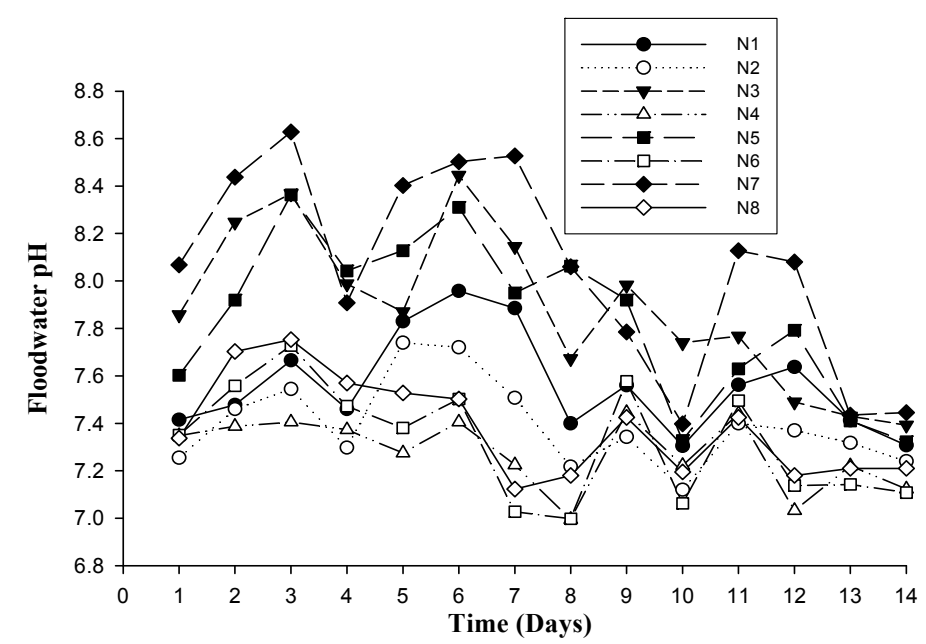

Figure 2. The effect of Azolla cover on floodwater $\mathrm{pH}$ in E1 plots for the first 14 days after urea application.

On-station field experiment in Dano, Burkina Faso

Note. $\mathrm{N} 1=0 \mathrm{~kg} \mathrm{~N}^{-1}$ without Azolla; $\mathrm{N} 2=0 \mathrm{~kg} \mathrm{~N} \mathrm{ha}^{-1}$ with Azolla; $\mathrm{N} 3=40 \mathrm{~kg} \mathrm{~N}^{-1}$ without Azolla; $\mathrm{N} 4=40$ $\mathrm{kg} \mathrm{N} \mathrm{ha}{ }^{-1}$ with Azolla; N5 $=80 \mathrm{~kg} \mathrm{~N} \mathrm{ha}^{-1}$ without Azolla; N6 $=80 \mathrm{~kg} \mathrm{~N} \mathrm{ha}^{-1}$ with Azolla; N7 $=120 \mathrm{~kg} \mathrm{~N}^{-1}$ without Azolla; $\mathrm{N} 8=120 \mathrm{~kg} \mathrm{~N} \mathrm{ha}^{-1}$ with Azolla.

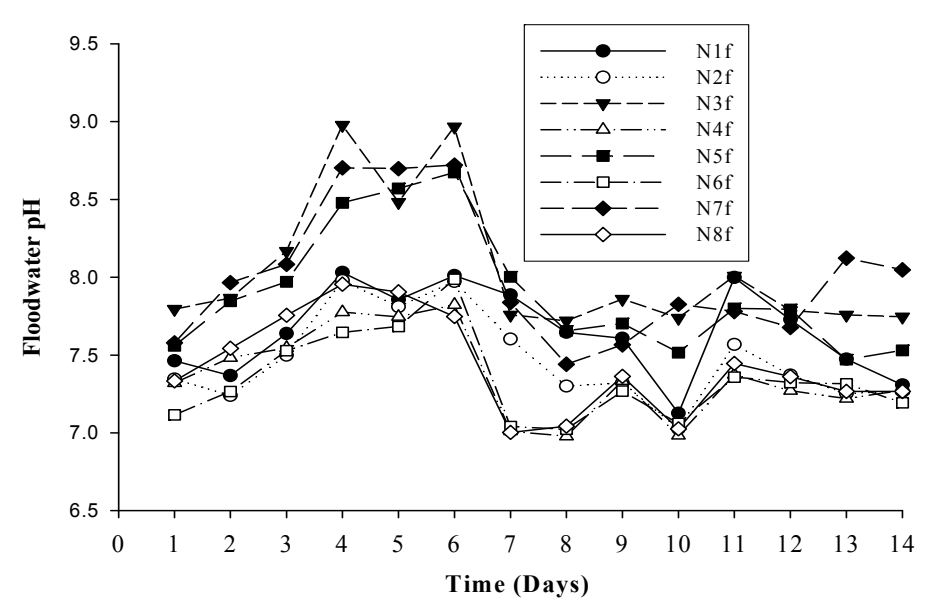

Figure 3. Effect of Azolla on floodwater $\mathrm{pH}$ on E2 plots the first 14 days after urea application. On-station field experiment in Dano, Burkina Faso

Note. $\mathrm{N} 1 \mathrm{f}=0 \mathrm{~kg} \mathrm{~N}^{-1}$ without Azolla; $\mathrm{N} 2 \mathrm{f}=0 \mathrm{~kg} \mathrm{~N}^{-1}$ with Azolla; $\mathrm{N} 3 \mathrm{f}=40 \mathrm{~kg} \mathrm{~N}^{-1}$ without Azolla; $\mathrm{N} 4 \mathrm{f}=$ $40 \mathrm{~kg} \mathrm{~N}^{-1}$ with Azolla; N5f $=80 \mathrm{~kg} \mathrm{~N}^{-1}$ without Azolla; $\mathrm{N} 6 \mathrm{f}=80 \mathrm{~kg} \mathrm{~N}^{-1}$ with Azolla; $\mathrm{N} 7 \mathrm{f}=120 \mathrm{~kg} \mathrm{~N}$ $\mathrm{ha}^{-1}$ without Azolla; $\mathrm{N} 8 \mathrm{f}=120 \mathrm{~kg} \mathrm{~N}^{-1}$ with Azolla. 


\subsubsection{Floodwater Temperature}

The influence of Azolla cover on floodwater temperature was highly significant $(p<0.01)$ in both E1 and E2.

Floodwater temperature were generally lower in plots with Azolla cover in both E1 and E2 (Figures 4 and 5). In the E1, floodwater temperature ranged from 32.3 to $32.7^{\circ} \mathrm{C}$ on plots without Azolla cover. Plots with Azolla cover had lower temperatures varying from $29.5{ }^{\circ} \mathrm{C}$ to $30.4{ }^{\circ} \mathrm{C}$. There was no clear pattern to the reduction of floodwater temperature by the presence of Azolla. The highest and lowest temperature difference between treatments with and without Azolla cover were recorded in E1 treatments with a temperature difference of $4.7^{\circ} \mathrm{C}$ and $0.1{ }^{\circ} \mathrm{C}$ respectively. In E2, the highest temperature difference of $4.0{ }^{\circ} \mathrm{C}$ and the lowest $0.3{ }^{\circ} \mathrm{C}$ were observed. Azolla reduced mean floodwater temperature in E1 treatment, and more so at lower $\mathrm{N}$ rates. For a period of 14 days the reduction was $2.0{ }^{\circ} \mathrm{C}$ for $0 \mathrm{~kg} \mathrm{~N} \mathrm{ha}^{-1}, 1.9{ }^{\circ} \mathrm{C}$ in $40 \mathrm{~kg} \mathrm{~N}^{-1}, 1.5{ }^{\circ} \mathrm{C}$ in $80 \mathrm{~kg} \mathrm{~N}^{-1}$ and $1.1{ }^{\circ} \mathrm{C}$ in $120 \mathrm{~kg}$ $\mathrm{N} \mathrm{ha}{ }^{-1}$. Similarly in E2, temperature reduction due to the presence of Azolla cover were $1.9{ }^{\circ} \mathrm{C}, 2.0^{\circ} \mathrm{C}, 1.6{ }^{\circ} \mathrm{C}$ and $1.0{ }^{\circ} \mathrm{C}$ for $0,40,80$ and $120 \mathrm{~kg} \mathrm{~N}^{-1}$ respectivly.

General, floodwater temperature was slightly higher in E1 which was measured in June than that of the E2 which was measure in August. The average minimum and maximum air temperature for the 14 days period in June were slightly higher than in August.

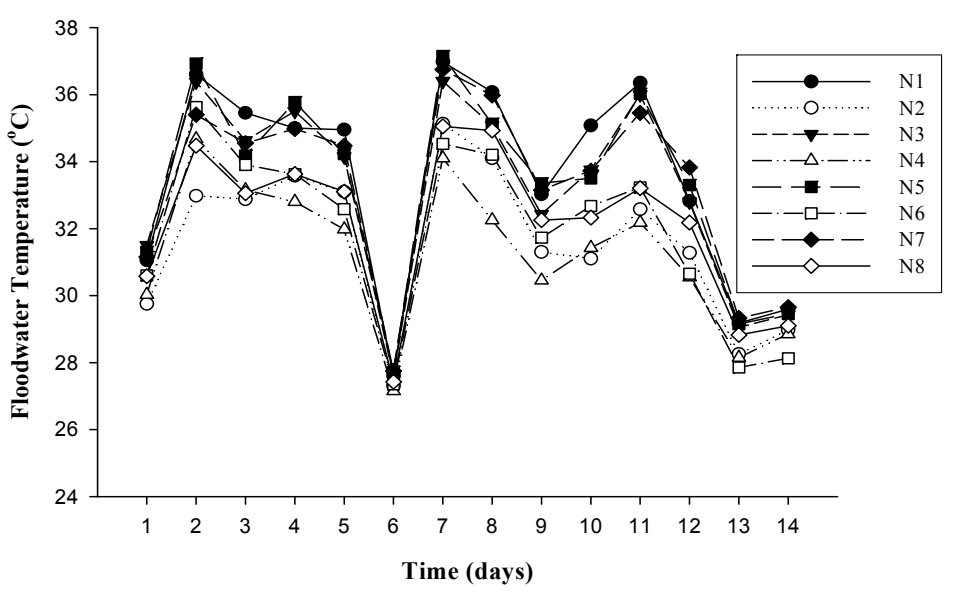

Figure 4. The influence of Azolla cover on floodwater temperature on E1 plot the first 14 days after basal urea application. Dano, Burkina Faso (For Note see Figure 2)

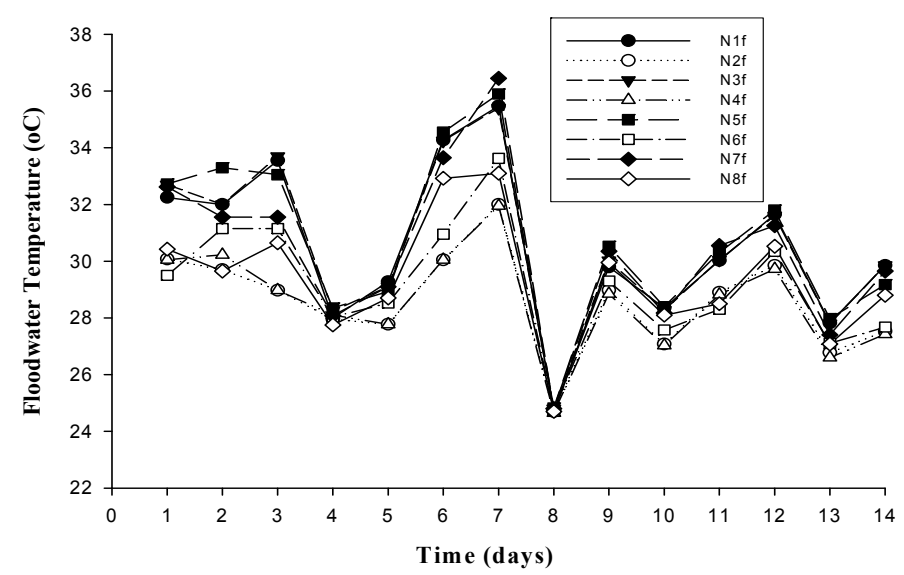

Figure 5. The effect of Azolla cover on floodwater temperature on E2 plots the first 14 days after top-dressed urea application. Dano, Burkina Faso

Note. $\mathrm{N} 1 \mathrm{f}=0 \mathrm{~kg} \mathrm{~N} \mathrm{ha}^{-1}$ without Azolla; $\mathrm{N} 2 \mathrm{f}=0 \mathrm{~kg} \mathrm{~N}^{-1}$ with Azolla; $\mathrm{N} 3 \mathrm{f}=40 \mathrm{~kg} \mathrm{~N}^{-1}$ without Azolla; N4f = $40 \mathrm{~kg} \mathrm{~N} \mathrm{ha}^{-1}$ with Azolla; N5f $=80 \mathrm{~kg} \mathrm{~N} \mathrm{ha}^{-1}$ without Azolla; N6f $=80 \mathrm{~kg} \mathrm{~N}^{-1}$ with Azolla; N7f $=120 \mathrm{~kg} \mathrm{~N}$ ha $^{-1}$ without Azolla; N8f $=120 \mathrm{~kg} \mathrm{~N}^{-1}$ with Azolla. 


\subsection{Plant Height}

Four weeks after transplanting, the effect of Azolla cover was obvious in the urea split application treatment (E1). Azolla significantly increased $(p<0.05)$ plant height by 5.4, 5.5, and 5.6\% compared to teatments without Azolla cover for 40, 80 and $120 \mathrm{~kg} \mathrm{~N} \mathrm{ha}^{-1}$, respectively. In E2, Azolla positively increased plant height but this increase was not statistically significant $(p>0.05)$. There was a strong increase in plant height at week eight. Azolla singnificantly increased $(p<0.01)$ plant height in N6 and N8 in E1. The highest value $(85.1 \mathrm{~cm})$ was measured in N8. Similarly in E2, Azolla cover significant increase $(p<0.05)$ plant height except N8f where the increase was not statistically significant (Figure 6).
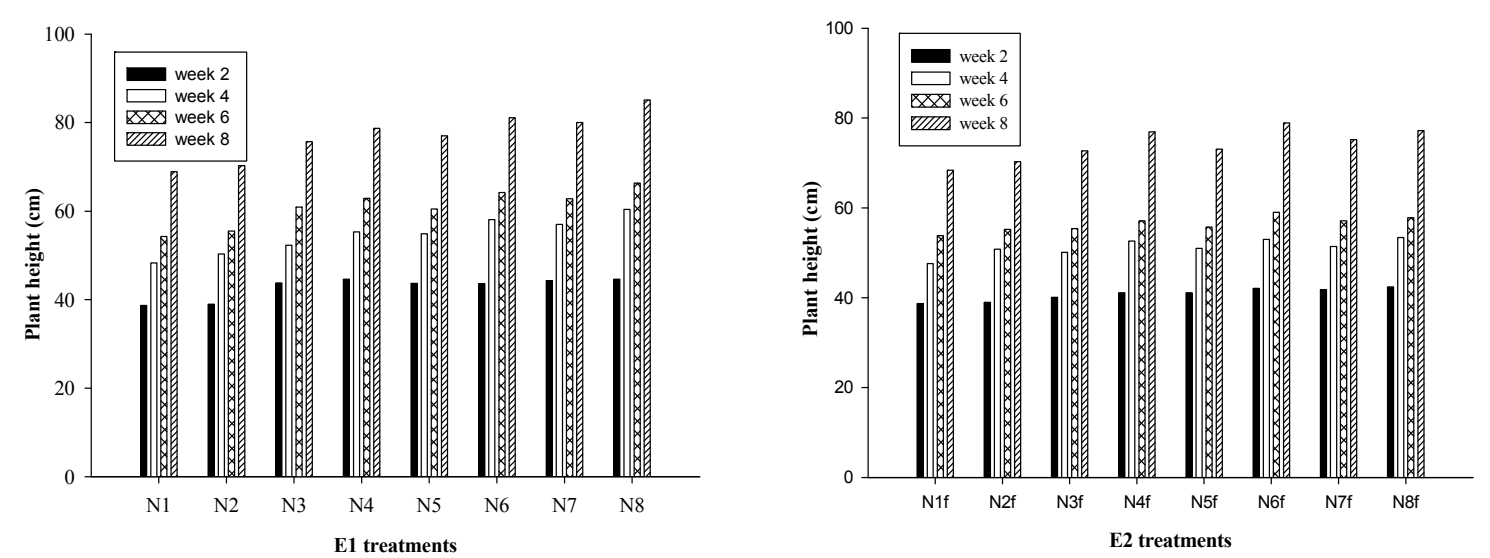

Figure 6. The effect of Azolla cover on plant height from two to eight weeks of transplant in E1 and E2. On-station field experiment. Dano, Burkina Faso

\subsection{Grain Yield}

Generally, nitrogen fertilizer $(\mathrm{N})$ significantly $(p<0.01)$ increased grain yield of rice up to $80 \mathrm{~kg} \mathrm{~N}^{-1}$. There was a slight decrease in yield beyond $80 \mathrm{~kg} \mathrm{~N} \mathrm{ha}^{-1}$. Figure 7 presents grain yield of rice in both experiments. Grain yield in E1 responded positively to both $\mathrm{N}$ and Azolla application with yields ranging from $2.61 \mathrm{t} \mathrm{ha}^{-1}$ in the control $(0 \mathrm{~N})$ to a maximum yield of $4.78 \mathrm{t} \mathrm{ha}^{-1}$ in $\mathrm{N} 8\left(120 \mathrm{~kg} \mathrm{~N} \mathrm{ha}^{-1}\right.$ and $2 \mathrm{t} \mathrm{ha}^{-1}$ Azolla). There was a significant increase $(p<0.01)$ in grain yield when $\mathrm{N}$ was applied irrespective of the application of Azolla. Similarly, there was a significant $(p<0.01)$ response of grain yield to the application of Azolla on floodwater. There was however no significant $(p>0.05)$ interactive effects of $\mathrm{N}$ and Azolla and between N, Azolla and method of fertilizer application (split application (E1) against single dose application (E2). Azolla increased grain yield by $3.9,6.4$ and $3.9 \%$ in $40(\mathrm{~N} 4), 80(\mathrm{~N} 6)$ and $120 \mathrm{Kg} \mathrm{N} \mathrm{ha}^{-1}$ (N8) respectively compared to treatments without Azolla cover on floodwater surface. The use of Azolla with $40 \mathrm{~kg} \mathrm{~N} \mathrm{ha}^{-1}$ produced grain yield equivalent to $80 \mathrm{~kg} \mathrm{~N}^{-1}$ without Azolla while $80 \mathrm{~kg} \mathrm{~N} \mathrm{ha}^{-1}$ with Azolla produced grain yield even higher than $120 \mathrm{~kg} \mathrm{~N}^{-1}{ }^{-1}$ without Azolla cover.

Similarly in E2, $\mathrm{N}$ and Azolla significantly increased $(p<0.01)$ grain yields. There was a positive interactive effect of $\mathrm{N}$ and Azolla; however, this was not statistically significant $(p>0.05)$. Application of $\mathrm{N}$ fertilizer increased grain yields ranging from $2.62 \mathrm{tha}^{-1}$ in N1f to a maximum of $4.68 \mathrm{tha}^{-1}$ in N8f. The presence of Azolla cover on the floodwater surface increased the grain yield by $1.9,7.0$ and $5.6 \%$ for $\mathrm{N}$ concentration of 40,80 and $120 \mathrm{~kg} \mathrm{~N} \mathrm{ha}^{-1}$, respectively.

Generally grain yields were higher with urea split application (E1) compared to single dose application (E2) by $14.5,6.1$ and $2.1 \%$ for 40,80 and $120 \mathrm{~kg} \mathrm{~N} \mathrm{ha}^{-1}$, respectively. 


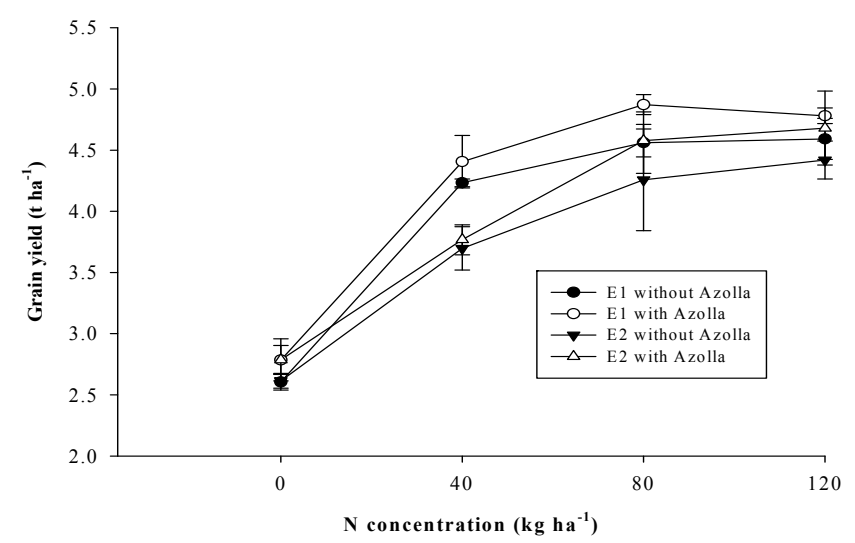

Figure 7. The effect of Azolla cover on grain yield of rice at harvest. On-station field experiment in Dano, Burkina Faso

\subsection{Straw Yield and Total Biomass at Harvest}

Nitrogen and Azolla significantly $(p<0.01)$ increased strew yield in E1 (graph not shown). Strew yield ranged from a minimum of $1.51 \mathrm{t} \mathrm{ha}^{-1}$ (N1) to a maximum of $3.72 \mathrm{t} \mathrm{ha}^{-1}(\mathrm{~N} 8)$ while in E2, strew yield ranged from a minimum of $1.50 \mathrm{t} \mathrm{ha}^{-1}$ in N1f to a maximum of $3.26 \mathrm{t} \mathrm{ha}^{-1}$ in N8f. In E1, the presence of Azolla increased the straw yield by $7.6(\mathrm{~N} 2), 14.2(\mathrm{~N} 4), 12.2(\mathrm{~N} 6)$ and $13.6 \%(\mathrm{~N} 8)$ over plots without Azolla (N1, N3, N5 and N7), respectively with the maximum yield of $4.06 \mathrm{t} \mathrm{ha}^{-1}$ in N6. In E2, the presence of Azolla increased the straw yield of rice but this increase was not statistically significant $(p>0.05)$. In both experiment, there were no interactive effect between Azolla, $\mathrm{N}$ and $\mathrm{N}$ application method.

Similarly, nitrogen and Azolla significantly $(p<0.01)$ increased total dry matter (TDM) of rice in both E1 and E2 (Figure 8). In E1, total dry matter yield ranged from a minimum of $4.2 \mathrm{tha}^{-1}(\mathrm{~N} 1)$ to a maximum of $8.8 \mathrm{tha}^{-1}(\mathrm{~N} 8)$ while in E2, TDM ranged from a minimum of $4.2 \mathrm{t} \mathrm{ha}^{-1}$ (N1f) to a maximum of $8.4 \mathrm{t} \mathrm{ha}^{-1}$ (N8f). There was interactive effect between Azolla and N, however this was not significant $(p>0.05)$. In addition, there was no significant interactive effect in all three factors (Azolla $\mathrm{x}$ nitrogen $\mathrm{x}$ method of $\mathrm{N}$ application).

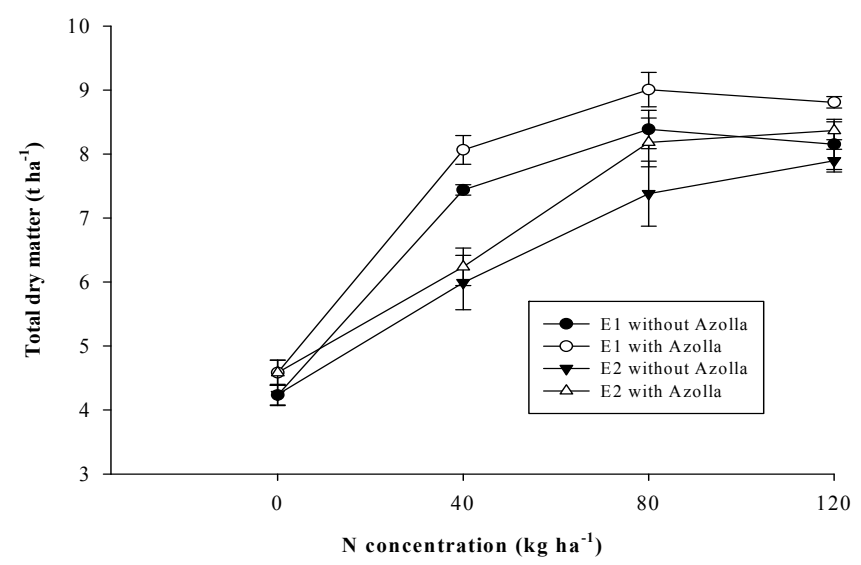

Figure 8. The effects of Azolla cover on total dry matter yield of rice. On station field experiment in Dano, Burkina Faso

\subsection{Grain, Straw Nitrogen Concentration and Total N Uptake at Harvest}

In both $\mathrm{E} 1$ and $\mathrm{E} 2, \mathrm{~N}$ significantly $(p<0.01)$ increased grain $\mathrm{N}$ concentration. Percentage grain $\mathrm{N}$ concentration ranged from 0.77 to 1.15 in E1 and 0.76 to 1.17 in E2. The presence of Azolla on floodwater surface further increased grain $\mathrm{N}$ concentration but the increase was not statistically significant $(p>0.05)$ in both E1 and E2 (Figure 9). In E1 the highest difference in grain $\mathrm{N}$ concentration (6.1\%) between plots with Azolla and plots without Azolla was recorded in N4. There was no interactive effects between N and Azolla on grain N concentration in both experiments. 
Similarly in E1, the presence of Azolla on floodwater surface increased straw N concentration by 14.9, 3.3 and $1.8 \%$ for 40,80 and $120 \mathrm{~kg} \mathrm{~N} \mathrm{ha}^{-1}$, respectively while in E2, the increase ranged from 1.3 to $11.9 \%$ with the highest increase (11.9\%) recorded in N4f.

In both experiments, $\mathrm{N}$ and Azolla significantly $(p<0.01)$ increased total $\mathrm{N}$ uptake (Figure 10). Total $\mathrm{N}$ uptake ranged from $57.4 \mathrm{~kg} \mathrm{ha}^{-1}$ in the control to $167.5 \mathrm{~kg} \mathrm{ha}^{-1}$ in $120 \mathrm{~kg} \mathrm{~N} \mathrm{ha}^{-1}$ with Azolla (N8) in E1. There was however no significant interactive effect between $\mathrm{N}$ and Azolla. Similar trend was observed in E2 where total N uptake ranged from a minimum of $57.5 \mathrm{~kg} \mathrm{ha}^{-1}$ in the control to a maximum of $160.7 \mathrm{~kg} \mathrm{ha}^{-1}$ in $120 \mathrm{~kg} \mathrm{~N} \mathrm{ha}^{-1}$ with Azolla (N8f).

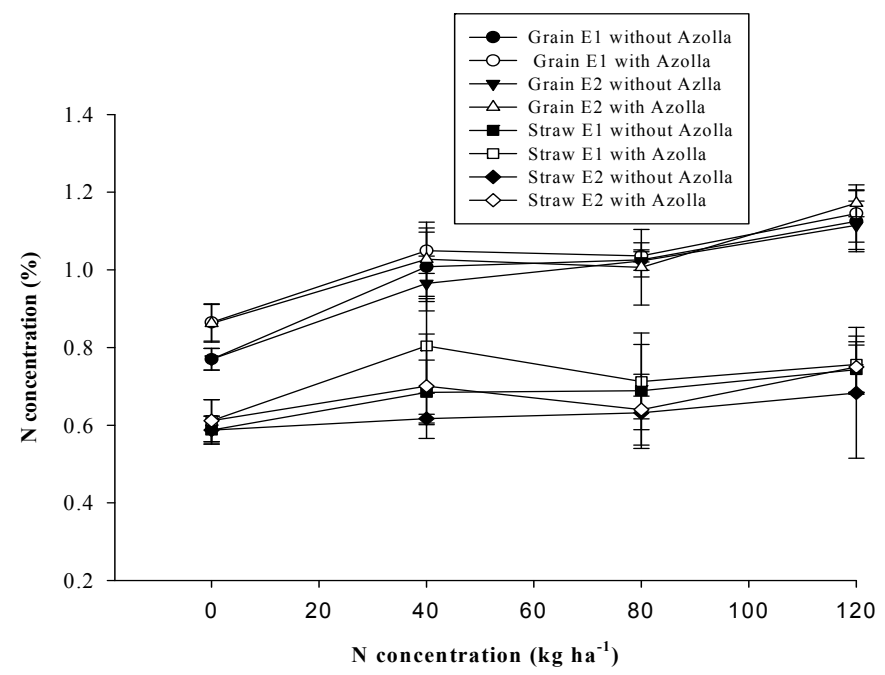

Figure 9. The effect of Azolla cover on grain and straw N concentration at harvest. On-station experiment in Dano

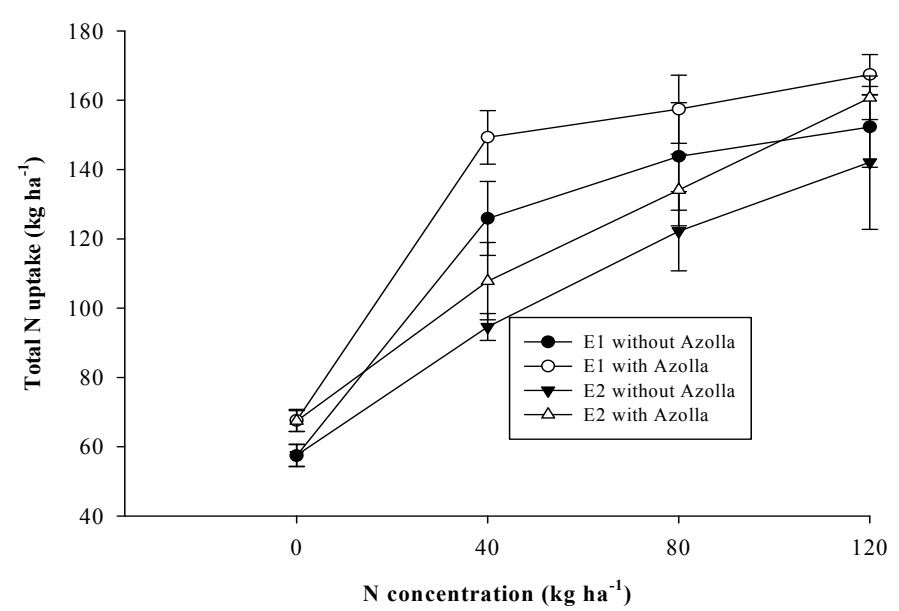

Figure 10. The effect of Azolla cover on total N uptake of rice at harvest. On-station experiment in Dano

\subsection{Apparent N Recovery}

The apparent nitrogen recovery (ANR) by rice plants from mineral fertilizer and Azolla in relation to the control is presented in Figure 11. The approach used does not take into account the effect of applied $\mathrm{N}$ on the transformation of native soil $\mathrm{N}$ nor the difference in soil $\mathrm{N}$ exploitation as determined by the increased size of the root system of the fertilized crops. As a result, the actual $\mathrm{N}$ recovery by the test crop may be overestimated.

Generally, ANR in grain was higher in E1 than in E2. Nitrogen and the presence of Azolla cover significant ( $p<$ $0.01)$ increased ANR in grain and strew in E1 (Figure 10). There was a significant $(p<0.05)$ increase in ANR only in grain in E2. There was however no significant interactive effects $(p>0.05)$ between Azolla and $\mathrm{N}$ in both $\mathrm{E} 1$ and E2. The method of application of $\mathrm{N}$ significantly $(p<0.01)$ increased ANR in both grain and strew yield 
in E1 and E2. In E1, the presence of Azolla cover, increased ANR by 13.3, 11.9, and 9.0\% in grain and 39.1, 22.9 and $21.6 \%$ in straw for 40,80 and $120 \mathrm{~kg} \mathrm{~N} \mathrm{ha}^{-1}$, respectively. Apparent $\mathrm{N}$ recovery generally decreased with increasing $\mathrm{N}$ concentration with the highest ANR in the grain (65.3\%) and in straw (48.6\%) in N4. In E2, the presence of Azolla improved ANR by 16.8, 9.8 and $16.1 \%$ in the grain, and in straw the increases were by 42.6 , 14.4 and $16.1 \%$ in N4f, N6f and N8f respectively.
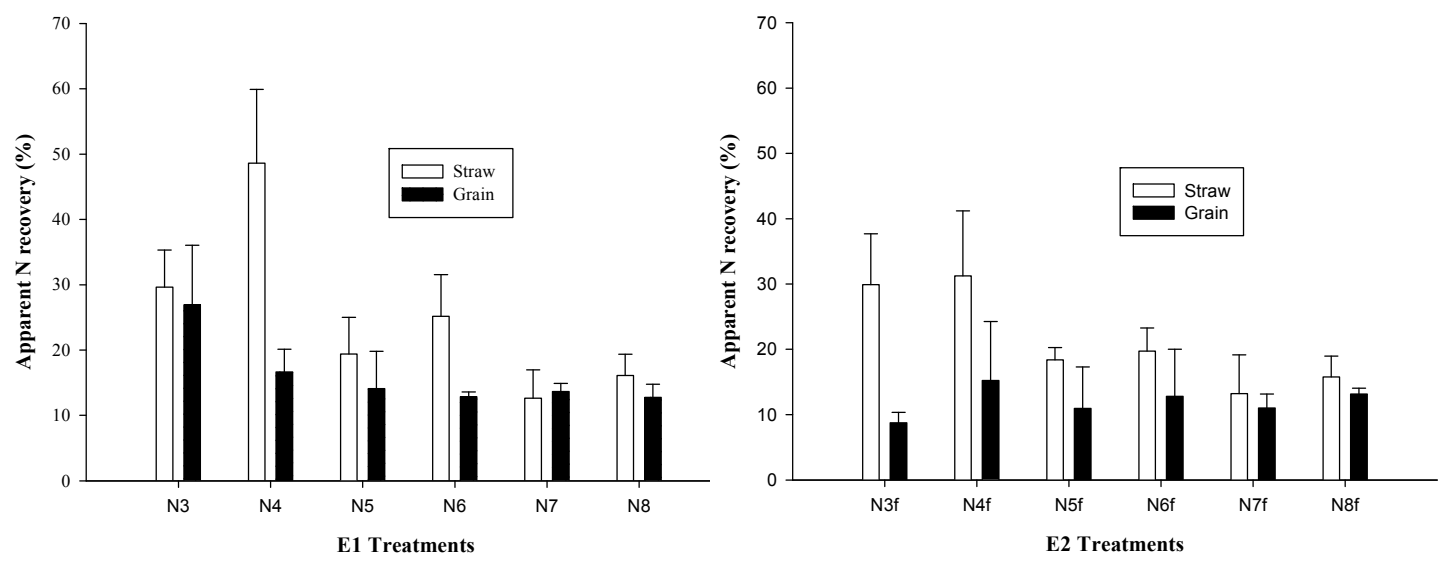

Figure 11. Apparent $\mathrm{N}$ recovery (\%) of rice as influence by Azolla cover in E1 and E2. On-station experiment in Dano, Burkina Faso. (For Note, see Figure 3 and 4)

\section{Discussion}

\subsection{The Chemistry of the Floodwater}

An increase in floodwater $\mathrm{pH}$ immediately after urea application could probalby be due to $\mathrm{OH}^{-}$production during urea hydrolysis. The presence of algae were observed in both E1 and E2 and this probabily brought about a further increase of the floodwater $\mathrm{pH}$. This finding is in line with a report by De Macale and Vlek, 2002 who stated up to 1.9 unit reduction in floodwater $\mathrm{pH}$ due to the presence of Azolla cover. However from the results obtained, the floodwater $\mathrm{pH}$ in E1, where the first rate of urea was applied one week after transplanting, $\mathrm{pH}$ value were less than 8.3 unit on the uncovered plots the first three days after urea application. Floodwater $\mathrm{pH}$ values below 8.3 during the first three days after urea application where most volatilization losses occur suggest that the increase in floodwater $\mathrm{pH}$ could likely be due to photosynthetic activity of algae. Furthermore, there was no reflection of suppressive effect of $\mathrm{HN}_{3}$ volatilization losses by Azolla in the yield, suggesting that $\mathrm{NH}_{3}$ volatilization losses were not a major problem.

In E2 where the application was done 45 days after planting, the rice plant had developed sufficient root system to take up nitrogen rapidly and avoid serious losses of $\mathrm{N}$ by volatilization, even though the $\mathrm{pH}$ of the uncovered plots rose up to 8.6 units during the first three days. The low $\mathrm{pH}$ values in plots with Azolla suggest that Azolla provided conditions that were not favorable for the growth of algae. This finding is in line with the finding of De Macale and Vlek (2002) in the Philippines and Andrea and Vlek (2007) who reported the lowering of floodwater $\mathrm{pH}$ in the presence of Azolla. With the use of the tracer technique, they showed a reduction of $\mathrm{N}$ losses from the system and an increase in ${ }^{15} \mathrm{~N}$ recovery by the rice plant. This was attributed in part to the reduced volatilization potential (lower floodwater $\mathrm{pH}$ ) and partly to the urea $\mathrm{N}$ up take by the Azolla. The effect of Azolla cover on floodwater $\mathrm{pH}$ was also explained in terms of its absorption of available light (De Macale \& Vlek, 2002). Azolla covering the floodwater surface absorbs incoming solar radiation, hence less light penetrated the floodwater. Vlek et al. (1995) speculated that this reduction in floodwater $\mathrm{pH}$ might be partly due to the respiration of Azolla, which increases the $\mathrm{CO}_{2}$ partial pressure in the water, but found this to be insignificant. Furthermore, the blue-green alga, Anabaena azollae, living in the fern's cavies, derives its carbon from the Azolla, (Tel-Or et al., 1991; Vlek et al., 2002), hence it does not contribute to increasing the floodwater $\mathrm{pH}$.

\subsection{Floodwater Temperature}

Another result of the shading effect of Azolla was the floodwater temperatures. The presence of Azolla cover significantly lowered floodwater temperature during the midday than in plots without Azolla cover. The presence of Azolla cover prevented the rapid heating of the floodwater. Cissé (2001) and De Macale and Vlek (2002) made similar observation in green house experiments. Floodwater temperature is a vital factor influencing $\mathrm{NH}_{3}$ 
volatilization. It affects the relative proportion of $\mathrm{NH}_{3}$ to $\mathrm{NH}_{4}$ present at a given $\mathrm{pH}$ (People et al., 1995). In an earlier study, Jayaweera and Mikkelsen (1990) found that increase in floodwater temperature from 10 to $40{ }^{\circ} \mathrm{C}$ at different $\mathrm{pH}$ values increased the aqueous $\mathrm{NH}_{3}$ in the floodwater resulting in its high losses per day.

\subsection{Crop Growth and Total Dry Matter}

Azolla, in combination with urea effectively increased the grain yield of rice compared to that of urea alone. The suppressive effect of Azolla on the growth of algae reduced the competition for $\mathrm{N}$ by the rice plant a week after transplanting. In addition, the additive effect of BNF by Azolla resulted in the improvement of the overall growth of the rice plant and hence higher grain yields. The plant height and the total dry matter yield confirm this. Cisse and Vlek (2001) made a similar observation and reported that Azolla conserved $\mathrm{N}$ by taking part of the urea applied, together with the $\mathrm{N}$ it fixed and then released it later. They added that the process does not only increase the availability of $\mathrm{N}$ to the rice plant but also ensured continues supply of $\mathrm{N}$ throughout the growth period of the rice plant. Thus the higher grain yield resulting from Azolla cover was also due to a higher $\mathrm{N}$ recovery of the applied urea by the rice plant.

\subsection{Nitrogen Uptake and Apparent N Recovery}

The presence of Azolla cover increased the plant $\mathrm{N}$ uptake in both experiments. Apparent nitrogen recovery (ANR) generally decreased with increasing $\mathrm{N}$ rate with the highest ANR in the grain. This is in line with the findings of Andrea and Vlek (2007), Bandyopadhyay and Sarkar (2005) and De Macale and Vlek (2002). Results from an ANOVA indicated no interactive effect between Azolla and $\mathrm{N}$ suggesting that the increase in the $\mathrm{N}$ uptake by the rice plant as a result of the presence of Azolla cover was most likely due to an additive effect of biological nitrogen fixation (BNF) by Azolla. Thus, the higher availability of $\mathrm{N}$ contributed to the vigorous growth of the rice during the vegetative stage. The combined effect of Azolla and urea application resulted in a higher $\mathrm{N}$ concentration in rice plant at harvest. The apparent $\mathrm{N}$ recovery of rice plant at harvest was higher with Azolla covered plots than those without Azolla cover in both experiments. Results of ANOVA showed no interactive effect between Azolla and N, hence, affirming that the increase of ANR was most likely due to an additive effect of BNF by Azolla.

\section{Conclusion and Recommendations}

The results provides evidence that the use of Azolla as a cover on floodwater surface of rice improved $\mathrm{N}$ avaliability to the plant through $\mathrm{BNF}$. In addition, $\mathrm{NH}_{3}$ volatilization losses is not a major problem in the study area (Dano). Results provides evidence that $\mathrm{N}$ uptake was improved by the use of Azolla which provided more $\mathrm{N}$ to the rice plant. Azolla cover brought about changes in the floodwater chemistry and in the physical and microbiological environment. Furthermore, the experiment demonstrated that the presence of Azolla cover reduced the extent of the rise of floodwater $\mathrm{pH}$ after urea application. In addition, Azolla cover prevented the growth of algal on the floodwater surface.

Azolla cover on the floodwater surface resulted in a higher grain yield. The combined effect of Azolla and urea produced grain yield ranging 3.9 to $7.0 \%$ higher than those without Azolla cover. The presence of Azolla cover with $40 \mathrm{~kg} \mathrm{~N} \mathrm{ha}^{-1}$ produced grain yield equivalent to $80 \mathrm{~kg} \mathrm{~N} \mathrm{ha}^{-1}$ without Azolla while $80 \mathrm{~kg} \mathrm{~N}^{-1}$ with Azolla produced grain yield higher than $120 \mathrm{~kg} \mathrm{~N} \mathrm{ha}^{-1}$ without Azolla. This prospect is very attractive in this part of the world where the cost of $\mathrm{N}$ fertilizer are high and there is growing need to improve grain yield to feed the increasing population. The application of Azolla can be an efficient and economic fertilizer alternative or supplement in flooded rice cropping system. The inoculation of Azolla to floodwater a week before rice transplanting was effective as it allowed the Azolla to have adequate time to spread and cover the floodwater surface at the time of urea application. This prevented algal growth and hence competition for N. It also provided the necessary Azolla biomass for effective BNF. The amount of $\mathrm{N}$ fixed by the fern and the recovery of the fixed $\mathrm{N}$ by the rice plant was however not known. It is therefore recommended that a further study be conducted using ${ }^{15} \mathrm{~N}$ to determine the uptake of the $\mathrm{N}$ applied, the total amount of fixed and released $\mathrm{N}$ by Azolla into the system. It is also recommended that, further studies be carried out to assess the cost-benefit of using Azolla in lowland rice-cropping system in Dano.

\section{Acknowledgements}

The authors greatly appreciate financial support from the German Federal Ministry for Education and Research (BMBF) through GLOWA-VOLTA project to conduct this research.

\section{References}

Andrea, M. K., \& Vlek, P. L. G. (2007). Azolla as a technology to improve the nitrogen use efficiency of lowland rice. Agriculture \& Rural Development, 2. 
Anderson, J. M., \& Ingram, J. S. I. (1996). Tropical Soil Biology and Fertility: A handbook of methods. CAB International, Wallingford, UK.

Bandyopadhyay, K. K., \& Sarkar, M. C. (2005). Nitrogen Use Efficiency, ${ }^{15} \mathrm{~N}$ Balance, and Nitrogen Losses in Flooded Rice in an Inceptisol. Communications in Soil Science and Plant Analysis, 36(11-12), 1661-1679. http://dx.doi.org/10.1081/CSS-200059114

Blaise, D., \& Prasad, R. (1995). Effect of blending urea with pyrite or coating urea with polymer on ammonia volatilization from surface applied prilled urea. Biol. Fertil. Soils, 20, 83-85. http://dx.doi.org/10.1007/BF00307846

Boadilla, E. L. (1993). Effect of Azolla cover on urea broadcast in flooded soils (M.Sc. Agr. Thesis). Georg-August-Universität Göttingen, Germany.

Bremner, J. M., \& Mulvaney, V. A. (1982). Steam distillation methods for ammonium nitrate and nitrite. Anal Chim Acta, 32, 485-495. http://dx.doi.org/10.1016/S0003-2670(00)88973-4

Byrnes, B. H., \& Freney, J. R. (1995). Recent development of the use of urease inhibitorsin the tropics. Fertilizer Res., 42, 251-259. http://dx.doi.org/10.1007/BF00750519

Cissé, M., \& Vlek, P. L. G. (2001). Impact of Azolla on urea-N cycling in flooded rice in comparison to and in combination with fertilizer placement, application of potassium chloride (KCl) and biocides (Dr. agr. Dissertation). Georg-August-Universität Göttingen, Germany.

De Macale, M. A. R., Vlek, P. L. G., \& San Valentin, G. O. (2002). The role of Azolla cover in improving the nitrogen use efficiency of lowland rice (Dr agr dissertation). Center for Development Research (ZEF), Ecological and Development Series (Vol. 2). University of Bonn.

Fageria, N. K., Dos Santos, A. B., \& Cutrim, V. dos A. (2009). Nitrogen uptake and its association with grain yield in lowland Rice genotypes. Journal of Plant Nutrition, 32(11), 1965-1974. http://dx.doi.org/10.1080/01904160903245121

Fageria, N. K., \& Baligar, V. C. (2001). Lowland rice response to nitrogen fertilization. Communications in Soil Science and Plant Analysis, 32, 1405-1429.

Freney, J. R., Keerthisinghe, D. G., Chaiwanakupt, P., \& Phongpan, S. (1993). Use of urease inhibitors to reduce ammonia loss following the application of urea to flooded rice fields. Plant and soil, 155/156, 371-375. http://dx.doi.org/10.1007/BF00025060

Fillery, I. R. P., \& Vlek, P. L. G. (1986). Reappraisal of the significance of $\mathrm{NH}_{3}$ volatilization as an N-loss mechanism in flooded rice fields. Ferti. Res., 9, 79-98. http://dx.doi.org/10.1007/BF01048696

Freney, J. R., Peoples, M. B., \& Mosier, A. R. (1995). Efficient use of fertilizer nitrogen by crops. Extension Bulletins. Food and Fertilizer Technology Center. Taiwan.

Fosu, M., Ku"hne, R. F., \& Vlek, P. L. G. (2004). Improving maize yield in the Guinea savannah zone of Ghana with leguminous cover crops and PK fertilization. $J$ Agron, 3(2), 115-121. http://dx.doi.org/10.3923/ja.2004.115.121

Jayaweera, G. R., \& Mikkelsen, D. S. (1990). Ammonia volatilization from flooded soil systems. A computer model, I. Theoretical aspects. Soil Sci. Soc. Am. J., 54, 1447-1455. http://dx.doi.org/10.2136/sssaj1990.03615995005400050040x

Knoblauch, R. P., Ernani, R., Walker, T. W., Krutz, L. J., Varco, J. J., Gatiboni, L. C., \& Deschamps, F. C. (2012). Ammonia volatilization in waterlogged soils influenced by the form of urea application. Rev. Bras. Cienc. Solo, 36(3), 813-822. http://dx.doi.org/10.1590/S0100-06832012000300012

Lumpkin, T. A., \& Plucknett, D. L. (1982). Azolla as green manure: Use and management in crop production. Westview Tropical Agricultural Series, 230(5).

Main, M. H. (1993). Propect of Azolla and blue green algae as nitrogenous biofertilizer for rice production in Bangladesh. Advances in Crop Science (pp. 34-35). Proceeding of First Biennial Conference of the Crop Science Society of Bangladesh.

Mian, M. H., \& Azmal, A. K. M. (1989). The response of Azolla pinnate R. Brown to the splite of application of Phosphorus and the transfer of assimilated phosphorus flooded rice plants. Plants and Soil, 119, 211-216. http://dx.doi.org/10.1007/BF02370410

Peoples, M. B., Freney, J. R., \& Moier, A. R. (1995). In P. E. Bacon (Ed.), Minimizing gaseous losses of nitrogen 
in Nitrogen fertilizer in the environment (pp. 565-590). Woodlots and wetlands Pty. Ltd. Sydney, Australia.

Schnier, H. F., de Datta, S. K., Mengel, K., Marqueses, E. P., \& Faronilo, J. E. (1988). Nitrogen use efficiency, floodwater properties and nitrogen-15- balance in transplanted lowland rice as affected by liquide urea band pacement. Fertilizer Research, 16, 241-255. http://dx.doi.org/10.1007/BF01051374

Simpson, J. R., Muirhead, W. A., Bowmer, K. H., Cai, G. X., \& Freney, J. R. (1988). Control of gaseous nitrogen losses from urea applied to flooded rice soils. Fertilizer Research, 18, 31-47. http://dx.doi.org/10.1007/BF01064176

Song, Y. S., Fan, X. H., Lin, D. X., Yang, L. F., \& Zhou, J. M. (2004). Ammonia volatilization from paddy fields in the Taihu Lake region and its influence factors. Acta Pedologica Sinica, 41(2), 265-269.

Tel-Or, E, Rozen, A., Ofir, Y., Kobiler, D., \& Schönfeld, M. (1919). Metabolic relations and intercellular signals in the Azolla-Anabaena associations. Is J. Bot., 40, 171-181.

Vlek, P. L. G., Eberhardt, U., \& Aung, M. (2002). The role of Azolla in lowering the pH of simulated floodwater. Journal of Applied Botany, 76, 1-7.

Vlek, P. L. G., Diakite, M. Y., \& Mueller, H. (1995). The roll of Azolla in curbing ammonia volatilization from flooded rice systems. Fertilizer Research, 42, 165-174. http://dx.doi.org/10.1007/BF00750511

Vlek, P. L. G., Fugger, W., \& Biker, U. (1992). The fate of fertilizer $N$ under Azolla in wetland rice. Proc. $2^{\text {nd }}$ ESA Congress, August,1992. Warwick Univ., UK.

Vlek, P. L. G., \& Byrnes, B. H. (1986). The efficacy and loss of fertilizer N in lowland rice. Fertilizer Research, 9, 131-147. http://dx.doi.org/10.1007/BF01048699

Vlek, P. L. G., \& Craswell, E. T. (1981). Ammonia volatilization from flooded soils. Fertilizer Research, 2, 227-245. http://dx.doi.org/10.1007/BF01050196

Vlek, P. L. G., \& Stumpe, J. M. (1978). Effects of Solution Chemistry and Environmental Conditions on Ammonia Volatilization Losses from Aqueous Systems. Soil Sci. Soc. Am. J., 42, $416-421$. http://dx.doi.org/10.2136/sssaj1978.03615995004200030008x

Zhu, Z. (1997). Fate and management of fertilizer nitrogen in agriculture-systems. In Z. Zhu, Q. Wen, \& J. R. Freney (Eds.), Nitrogen in soil of China (pp. 239-279). Dordrecht, The Netherlands: Kluwer Academic Publishers. http://dx.doi.org/10.1007/978-94-011-5636-3

\section{Copyrights}

Copyright for this article is retained by the author(s), with first publication rights granted to the journal.

This is an open-access article distributed under the terms and conditions of the Creative Commons Attribution license (http://creativecommons.org/licenses/by/3.0/). 